IRSH 59 (2014), Special Issue, pp. 2 I I-235 doi:I0.10I7/S00208590I 4000340 (C) 2014 Internationaal Instituut voor Sociale Geschiedenis

\title{
"Human Telephone Lines": Flag Post Mail Relay Runners in British Southern Cameroon (1916-1955) and the Establishment of a Modern Communications Network
}

\author{
Walter Gam NKW I \\ Department of History, University of Buea \\ PO Box 63, Buea, Republic of Cameroon \\ E-mail: nkwiwally@yahoo.com
}

MirJam DE BRUIJN

African Studies Centre, Institute for History, Leiden University

PO Box 9500, 2300 RA Leiden, The Netherlands

E-mail: m.e.de.bruijn@hum.leidenuniv.nl

\begin{abstract}
The flag post mail relay runners, a communications system established in Cameroon during British colonial rule, laid the foundations for the communications structure of this colonial state. They were a remnant of a pre-colonial communications system and, with the advancement of "modern" communications structures such as roads, telephone lines, and post houses, the flag post runner gradually disappeared. This article explores the role of the runners for the colonial administration in Cameroon and is based mostly on archival research. It describes the runners' system and how it influenced the colonial communications landscape. In addition, the questions of how these runners were involved in the colonial state and what forms of resistance emerged among runners are analysed. Finally, the article discusses the degree to which the subsequent construction of roads, telegraphic communications, and postal networks reflected the role played by mail runners in the British colonial period up to the r95os.
\end{abstract}

\section{INTRODUCTION}

Communication is one of the backbones of governance and power relations, ${ }^{\mathrm{I}}$ and therefore understanding communications systems and changes

I. Manuel Castells, Communication Power (Oxford, 2009); James Gleick, The Information: A History, a Theory, a Flood (London, 20 I I); Mirjam de Bruijn and Rijk van Dijk (eds), The Social Life of Connectivity in Africa (New York, 201 I). 
therein will reveal insights into expected and unexpected power relations and the "making" of power in colonial history. In this article, communications systems comprise all the various ways of organizing communication through the exchange of mail and information with the aid of communications technologies. Important issues include the question of who defines and organizes communications systems and their access rules. What is the history of the communications technologies, and on which and whose ideology are they based? Whose needs are served through this system? The introduction of colonial communications technologies was part of the "modernization" project, of which colonial policies were also part, opening up the hinterland and organizing a "modern" state, a new form of governance. This was not without its problems, including the need to overcome the obstacles of inaccessible roads, long distances, and underpopulation in the larger part of the territory in order to get information and mail moving, and also new forms of resistance.

For British colonial Cameroon, transport and mobility have been little studied. Walter Gam Nkwi's study is an exception, and forms a starting point for the present article. ${ }^{2}$ Based on archival research conducted in the Buea National Archives in Cameroon, the Mission 2I Archives in Basel (Switzerland), and the Mill Hill Archives in Oosterbeek (The Netherlands), this article describes the communications systems in Cameroon during the British colonial period from 1916 until the 1950s, focusing on the flag post mail runners. These constituted a kind of "human telephone line". Grasping the reality of this "human telephone line", both in its role as a communications operation and as a lived reality for the runners themselves, is the main aim of this article.

The central question is how this communications system - based on human labour rather than technical devices - formed the basis of later communications technologies, such as the telegraph, road networks, and the telephone. How did the organization of these "human telephone lines" represent flows of information? Probably most importantly for our enquiries here: who were the runners, and how was their labour organized? And how did this organization lay the foundation for a future communications network? One of the ideas underlying this article is that previous systems of communication influence subsequent ones. ${ }^{3}$ How did the network of runners and their organization lay the foundations for the communications system, therefore contributing to the foundation of power relations in the late colonial and postcolonial Cameroonian economy and society?

2. See Walter Gam Nkwi, Kfaang and its Technologies: Towards a Social History of Mobility in Kom, Cameroon, 1928-1998 (Leiden, 20II).

3. Aad Blok, "Introduction", International Review of Social History, 48 (2003), Supplement I I, "Uncovering Labour in Information Revolutions, I750-2000", pp. I-I I. 
This article aims to contribute to the knowledge of communication and labour in the social history of Africa, specifically in Cameroon, and seeks to understand power relations between the colonial administration and the mail runners, for whom working for the colonial administration was a way to accumulate wealth and thus enhance their position and power. The world of the mail runner has, at the same time, to be understood as part of a global labour force, which emerged in this period in the context of the colonial system of domination, strongly characterized by exploitation and various forms of forced recruitment, and by systematic attempts by the colonial powers to regulate and control labour relations, which is a characteristic, of course, of every labour regime. ${ }^{4}$

Literature on the topic, especially in relation to labour, is scant. Allied to our topic are the scarce publications on roads and transport. For instance, Stephen Rockel was one of the first researchers to write on transport and transport routes in east and central Africa. ${ }^{5}$ The flag post mail runners in Cameroon were not a unique phenomenon; various kinds of runners, messengers, and other communications workers have also existed in other regions of the British Empire, notably in India, and have attracted some attention from historians. Chitra Joshi, for instance, has shown how a similar system of runners played a role in reordering communications networks during the British colonial administration in India. Others have studied the role of the runners, messenger boys, and other workers, and their forms of resistance. ${ }^{6}$ These studies have been very useful in helping us to understand the communications systems among human runners in British Cameroon in the early twentieth century.

This article draws on both official and non-official sources. ${ }^{7}$ It will first trace the beginnings of the flag post mail runner system and how it drew

4. Jan Lucassen (ed.), Global Labour History: A State of the Art (Bern, 2006); Marcel van der Linden, "Labour History: The Old, The New and the Global”, African Studies, 66 (2006), pp. I69-180.

5. See Stephen Rockel, Carriers of Culture: Labor on the Road in Nineteenth-Century East Africa (Portsmouth, NH, 2006).

6. Chitra Joshi, "Dak Roads, Dak Runners, and the Reordering of Communication Networks", International Review of Social History, 57 (201 2), pp. I69-189; Deep Kanta Lahiri Choudhury, "India's First Virtual Community and the Telegraph General Strike of 1908", International Review of Social History, 48 (2003), Supplement I I, "Uncovering Labour in Information Revolutions, 1750-2000”, pp. 45-71; Gregory J. Downey, Telegraph Messengers Boys: Labor, Technology and Geography, 1850-1950 (New York, 2002).

7. The bulk of the material collected for this article was gathered from the Buea National Archives and the Provincial Archives of Bamenda, Cameroon. We examined files on flag post relay runners that had not so far been consulted. As is the case with many archives in Africa that had been set up by colonial administrations, the documents are now in poor condition as storage systems are inadequate, and many files have been destroyed by vermin. However, archival information alone cannot recount the whole story, and information provided by people willing to share with us their memories of the runners system was invaluable. The combination 
on traditional forms of communication to become an established and vital organization in the colonial administration. The second section moves on to the position of the runners themselves and considers who they were, their labour conditions, and how they and their position were perceived by the administrators and their co-subjects in the colonial society of the day. The third part examines the relationship between the runner system and the administration: its evolution, its moments of conflict, and its eventual disappearance.

\section{THE ORGANIZATION OF BRITISH COLONIAL CAMEROON AND THE FLAG POST MAIL RUNNER SYSTEM}

Before delving into the details of the mail runner system, an introduction to the organization and administration of this part of Cameroon in the early twentieth century is needed. After the end of World War I, the former German colony of Cameroon was divided into two parts. The western part, comprising about is per cent of the whole territory, came under British rule and the rest was mandated to the French. The British section was administered as an appendage to the British colony of Nigeria. British Southern Cameroon, which is the focus of this article, was made up of the divisions of Bamenda, Kumba, Victoria, Ossidinge (later Mamfe and Tinto), Nkambe, and Dschang. ${ }^{8}$ Kumba, Ossidinge, and Victoria were in the forest region of Southern Cameroon, while Bamenda and Dschang were in the grasslands region (see Figure I).

The divisions were split into subdivisions administered by Assistant Divisional Officers (ADO), who reported to the Divisional Officers (DO), who were responsible for the divisions. The DO answered to the Resident, who, in turn, reported to the Lieutenant Governor General in Enugu, Nigeria. He answered to the Governor General in Lagos and the Governor General reported to the Secretary of State for the Colonies

of these different sources helped to counterbalance the dominant voices of the colonial authorities found in the colonial archives. The photographs from the Mission 2I Archives in Basel and the Mill Hill Archives in Oosterbeek reproduced in this article do not show people running with mail, but rather runners carrying the heavier parcels of the colonial administrators to the hinterland. Walter Nkwi and Mirjam de Bruijn have worked together in Cameroon on the history of communications technologies and on recent developments surrounding the introduction of mobile telephony. For details of Walter Nkwi's Ph.D. research, which was funded by NWO-WOTRO (Project no. W OI.67.2007.014) and supervised by Mirjam de Bruijn, see http://mobileafricarevisited.wordpress.com/.

8. Dschang did not remain in British Southern Cameroon and was transferred to French Cameroon during the 1922 boundary changes agreed between France and Great Britain. See Neville Rubin, Cameroun: An African Federation (London, 1971). 


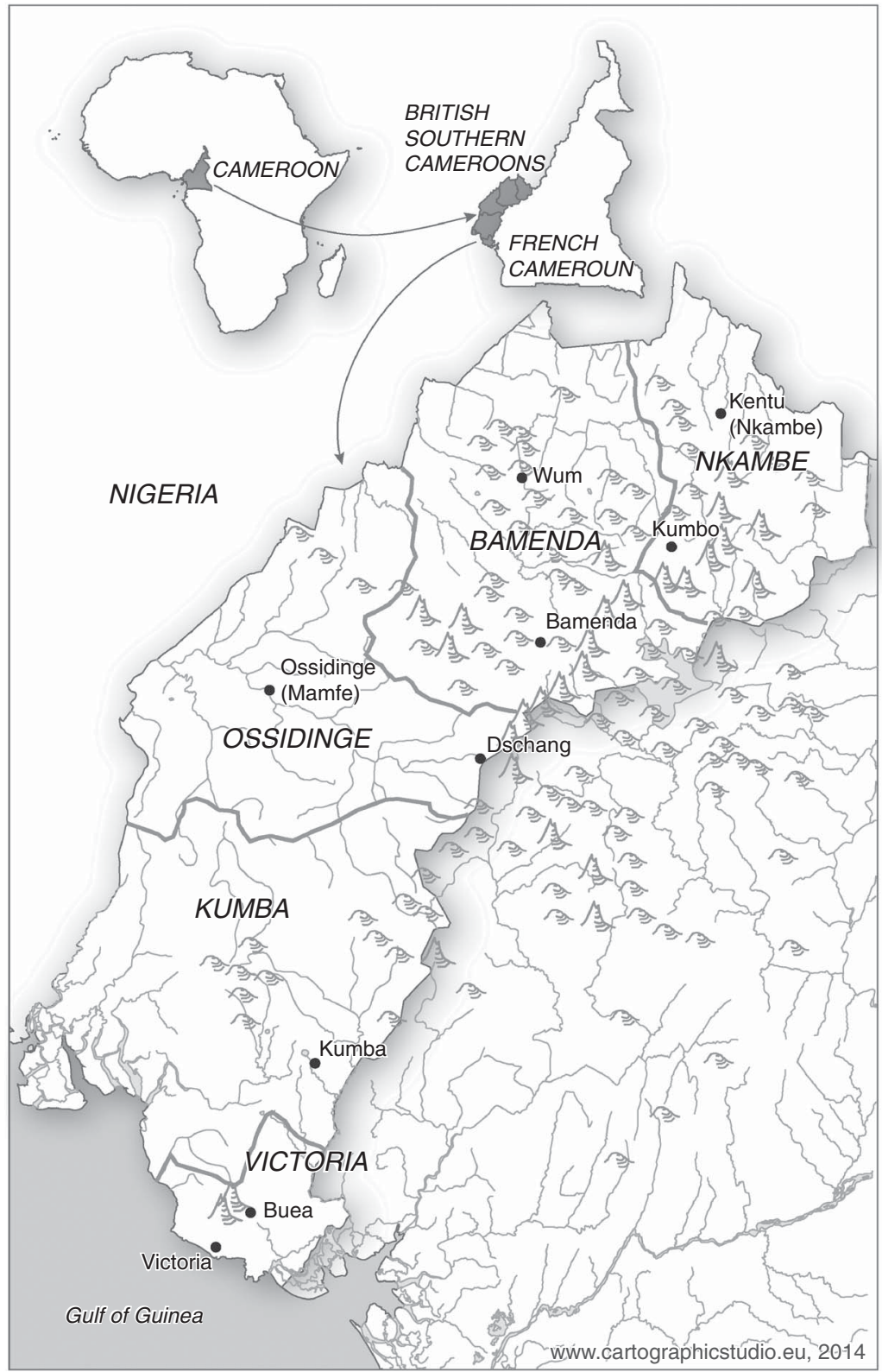

Figure I. Overview of British colonial Cameroon. 
in London. ${ }^{9}$ The flag post mail runner system developed within this administrative hierarchy.

\section{The importance of mail}

The objects transported comprised mail, as messages, and bulkier parcels/ goods. Mail as referred to in this article could therefore entail both messages in envelopes, and parcels and other smaller goods to be transported - the latter carried on the head of the runner. It could include the goods of colonial residents/missionaries going on transfer, or just arriving in the territory by sea to continue onwards into the hinterland. In both situations, mail runners were used to transport the goods.

The flag post mail runners were employed in the service of the British colonial administration to handle the movement of mail by running with it from one place to the next using a relay system. Each flag post was provided with a flag for the hut, hence the "flag post" in the system's name. ${ }^{\circ}$ Each district had different coloured flags, and the relevant colour was put on the envelope, waybill, or parcel bag. For instance, Bamenda division used red; white was for Dschang; Ossidinge was blue; blue and white were Kumba; and Buea was red and white. This meant that all mail addressed to Bamenda was labelled red and that Bamenda, in turn, would use the colours of the stations to which the mail was addressed. ${ }^{\text {II }}$ The colours were intended to avoid confusion when people who were unable either to read or write dispatched mail to the different districts. Introducing colours was one way in which the colonial system managed its subjects. It preferred to put colours on mailbags instead of teaching the "human telephone lines" to read and write in the colonial language. The few who were taught to read and write were intended to fill the posts of clerk, teacher, or bookkeeper that were essential to the colonial administration.

The flag posts were divided into two regions. The southern system included Buea-Rio, Buea-Tiko, and Victoria-Tiko and covered i9s miles. The northern sector covered Buea-Kumba-Tinto-Ossidinge-Ikom, Buea-Kumba-Tinto-Bamenda-Kentu, Buea-Kumba-Tinto-DschangMbo, and Dschang-Bamenda, a distance of 570 miles $^{\mathrm{I2}}$ (see Figure 2).

9. National Archives Buea [hereafter, NAB], File no. Cb (1917) 7, Report no. 3-1917 Cameroon Province Annual Report for Year ended December 1917.

Io. In this article, "runners" and "carriers" are used synonymously. They will be used interchangeably since their job descriptions were identical.

I I. NAB, File no. Ag/i Memorandum no. 90I/ıo from Resident's Office Buea, 23 December I916, Kumba-Victoria-Ossidinge-Chang-Bamenda.

I 2. NAB, Memorandum no. 354/1916 from the Resident's Office, E.C. Duff, Resident, Cameroon Province, Buea, 5 December 1916, to Post Master General, Lagos. The information on the number of total miles covered is taken from the original source. The method used to calculate the figures is not made explicit there. 


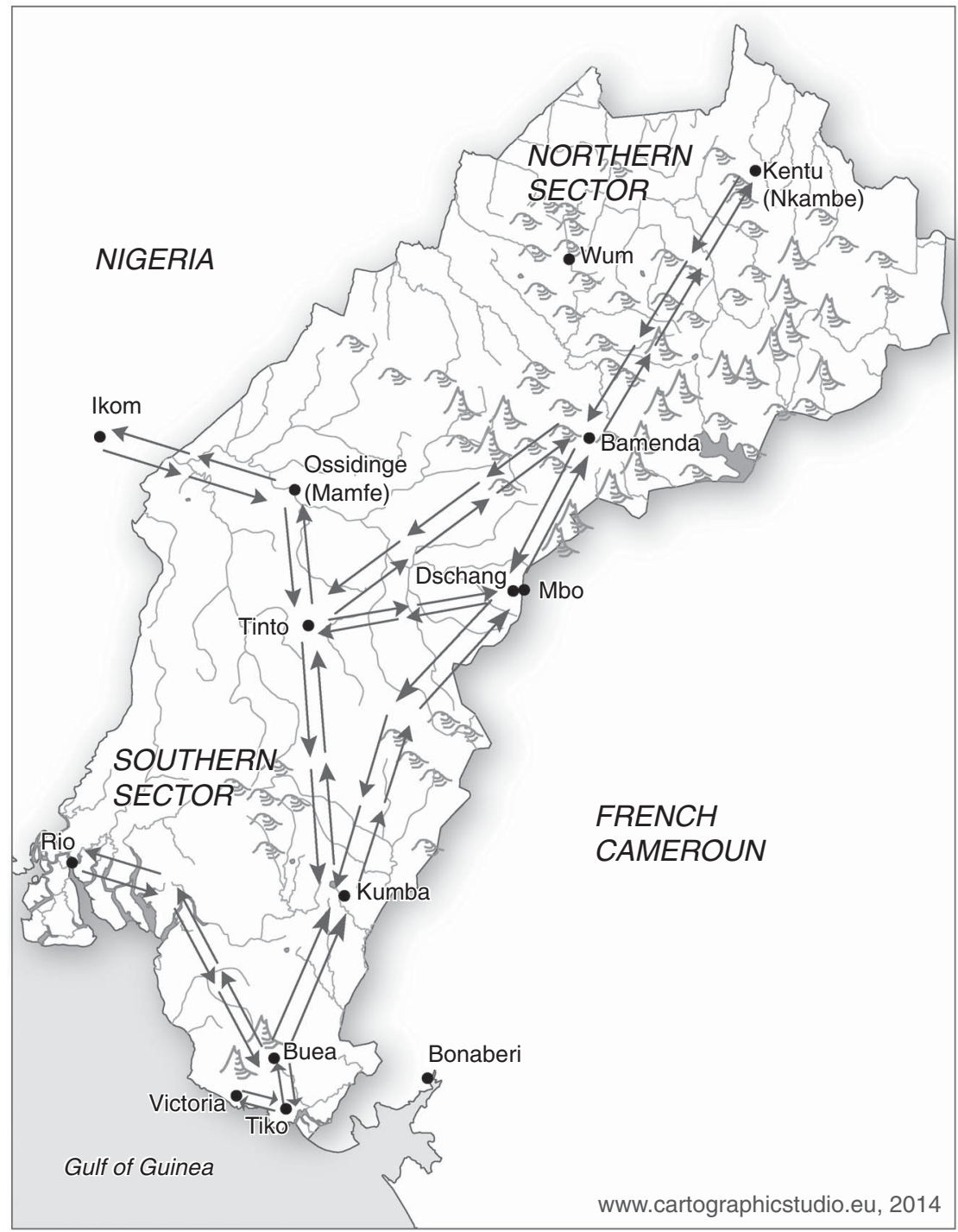

Figure 2. Movement of mail runners.

Each post had a hut that was staffed by three "boys", who worked in the hut for a month before being replaced. ${ }^{\mathrm{I} 3}$ Displaying the flags, houses or huts became "intimidating structures" that constantly reminded the

I 3. NAB, File no. Ad/6, Memorandum no. 339/1 5/17 from Assistant District Officer's Office, Kumba on Tour at Buea, 28 June 1917, to the Resident, Buea, titled "Flag Posts". 
population and the mail runners of the presence and importance of the colonial administration. It was not the hut itself that was intimidating, though. Rather it was what the population saw in the presence of the hut, namely colonialism.

The importance of mail and the role of the mail runners were captured in a memo from the Resident of the British Cameroon, E.C. Duff, to the Governor General, Lagos, on 5 December 19r6. He wrote as follows:

I have the honour to confirm my telegram No. 934 of 3 December 1916, which stated that there was four hundred pounds worth for carriage of inland mails. As you are aware, the distances in this Province are very great indeed, and communications so bad at present that the administration is greatly hampered by the delay in forwarding mail. The flag post mail runner system is infinitely quicker and the only way for the administration to solve the problem of mail. A day's run by mail runners can rarely be over 25 miles owing to the hills, rivers and forests but they must still cover 60 miles which is a great distance owing to the urgency of the mail difficulties and challenges notwithstanding $[\ldots]{ }^{\mathrm{I}}{ }^{4}$

Colonial officers, including the DO, ADO, and the Resident, were given instructions from their superiors and needed to know whether their annual revenues had been received by the Colonial Office in London. Also, all the other actors of colonial domination - businesses, missionaries, the police, travellers, doctors, and engineers - communicated by mail. The mail runners became the "lines" by which the colonial administration and European residents could ensure effective communication. In 1916 the total value of mail for the Bamenda division was estimated at $£_{2}, 400$, which amounted to 23 per cent of the total budget of $£_{10,280}$ and shows why the colonial administration attached so much importance to the system. ${ }^{\text {Is }}$ Bamenda division was the largest region, and heavily populated.

\section{The origins of the flag posts}

The colonial mail runners were based on the well-established pre-colonial communications system that had been set up by the local rulers in this part of Cameroon, where inter-chiefdom communication was achieved, in effect, using runners bearing messages. They were known as chindas or chisendos in the Grassfields region and carried royal messages and goods in relay to the next traditional polity. With the greater distances in the forest regions, the ngumbas (as the runners were called there)

I4. NAB, File no. 23/Ag Memorandum no. 354/1916 from Resident's Office, E.C. Duff, Resident, Cameroon Province, Buea, 5 December 1916, to Post Master General, Lagos. In most of the original sources found in the archives in Cameroon, first names were abbreviated. Most of the names in the present article, including E.C. Duff, are written thus.

I s. Ibid. For the budget figures see NAB, Cb 1918/2, Bamenda Province Annual Report for 1916-17 by L.S. Ward, ADO, and Major H.E.H. Crawford, DO. 
were charged with messages alone and never carried heavy loads for long distances. ${ }^{16}$

Another much older but related method of communication used in the territory were the talking drums, large, all-wood instruments made from a single log featuring hollow chambers and long narrow openings. ${ }^{17}$ Resonant tones are produced when they are struck with wooden sticks, and there are often small stands under each end of the drum to keep it off of the ground and to allow it to vibrate more freely. The bigger the log from which the drum is made, the louder the sound produced and thus the farther away it can be heard. A talking drum can be tuned to produce a lower or higher note. The drum's edges are hit with sticks as the drummers beat out rhythms of high and low notes. In the past, messages produced by a talking drum could reach the whole of a region. Messages were sent further on by those who were the last to receive them, and they would relay them to those still further afield. Within a short time, a message could be disseminated across a large region.

Both the older system of the pre-colonial messenger and the talking drum were based on covering huge distances in a short time: one through the carrying of sound, and the other through the human runner. The colonial administration was able to construct its own communications system on the basis of these earlier methods.

\section{The operation of the flag post mail runner system}

The operation of the mail runner system was detailed in a letter written by the Resident of the Cameroon Province, P.V. Young, to the SecretaryGeneral, Southern Provinces, Lagos, Nigeria. He wrote as follows:

The system at present working in theory is that the Transport Officer at Calabar wires to the District Officer, Ossidinge, and the details of loads for each Station. On receipt of this telegram by the District Officer, he wires details of the loads to the District Officers at Bamenda and Dschang who send off flag post mail carriers from their respective stations to Ossidinge. They are then sent down by the District Officer Ossidinge (75 miles) to meet the launch at Ikom and bring up the packages; but what in reality happens is that the telegraph is so uncertain that it very often takes days before a wire sent from Calabar reaches Ossidinge. The result of this is that days of delay arise before these boys are got off. The distances approximately are Ikom to Ossidinge 75 miles; Ossidinge to Bamenda 90 miles; Ossidinge to Dschang 85 miles; these mail runners so to say therefore travel from Ossidinge to Ikom and back I 50 miles; Bamenda to Ossidinge and

16. Bamenda Provincial Archives, Bamenda, File no. Ad (1948)/22 Dr Phyllis Kaberry, Lady Anthropologist. Intelligence Report on Wum and Nsaw, I948 (NAB); Ba 1927/I Cameroon Province League of Nations Annual Report for 1927.

17. Shirley Deane, Talking Drums: From a Village in Cameroon (London, 1985). 
Table I. Partial timetable showing mail departures and arrivals, and approximate distance and time taken.

\begin{tabular}{lllll}
\hline Departure & Day & Arrival & Day & Total no. of Days/Miles \\
\hline Kumba & Wednesday & Tinto & Monday & 6 days $/ 100$ miles \\
Tinto & Tuesday & Kumba & Sunday & 6 days $/ 100$ miles \\
Tinto & Tuesday & Dschang & Thursday & 3 days $/ 46$ miles \\
Dschang & Saturday & Tinto & Monday & 3 days $/ 46$ miles \\
Tinto & Tuesday & Bamenda & Sunday & 6 days $/ 100$ miles \\
Bamenda & Wednesday & Tinto & Monday & 6 days $/ 100$ miles \\
\hline
\end{tabular}

Source: NAB, File Rg (I917) 2 Flag Post System, with approximate distance and time taken.

back I 80 miles; Dschang to Ossidinge and back 170 miles. As regards this system, I would ask that the Transport Officer at Calabar be asked to promptly notify the District Officer, Ossidinge, of the number of packages and their destinations, care being taken by him to give the exact number of loads of each station and the number of boys needed. Thus it could be twenty loads for Bamenda and ten loads for Dschang. ${ }^{18}$

This excerpt emphasizes, first, the degree to which riverboat transportation and the mail runner system were interlocked (see Figure 4); second, it shows how difficult the mail runner system was in practice. It evidently operated within the limitations posed by the boats that brought in the mail and other goods from the metropolis. It also had to compensate for the deficiencies in telegraph lines in the territory. At places where the steamers or boats terminated, the flag post mail runner became vital to the colonial administrators. He was condemned to clear the thick bush before passing with his load or smaller parcels.

However, before examining the connections between water and mail runners, it is helpful to understand the rough timetable to which the mail runner was tied (see Table I above).

River transport was crucial to the effective operation of the system. All inland mail and other goods came by boat and were then transported further on to the various stations. The main stations for this boat transport were Tiko, Victoria, Ikom, and Bonaberi. Water tides determined when the launches anchored and set sail, and therefore influenced the times when the mail runners were able actually to take on the mail. The role water transport played, and its limitations, and the role of inter-imperial, British-French cooperation in transport are echoed by the Resident in the following:

An alternative which I might suggest, and which might take some reconsideration is that all transport shall be done via Victoria, Tiko and then to Bonaberi, thence 


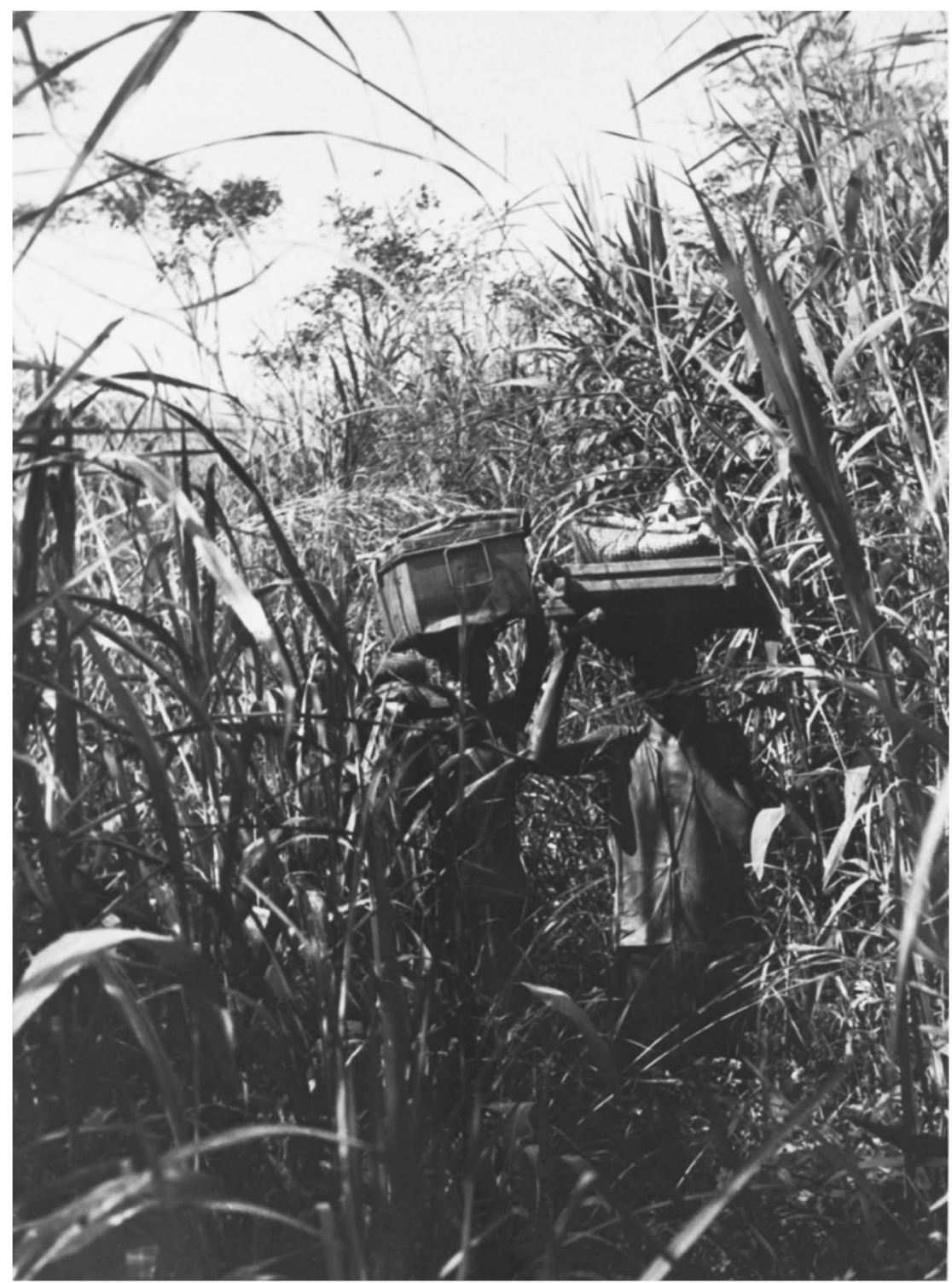

Figure 3. Carriers on trek in the Grassfields.

Mill Hill Archives, Oosterbeek (The Netherlands). Used with permission.

by the French Railway to Nkongsamba, by this route an enormous saving of carrier transport is affected. The distance from Nkongsamba to Dschang is about 52 miles and from Dschang to Bamenda 53 miles. The connections would be as follows: from Calabar there is a monthly boat running to Victoria and very often 


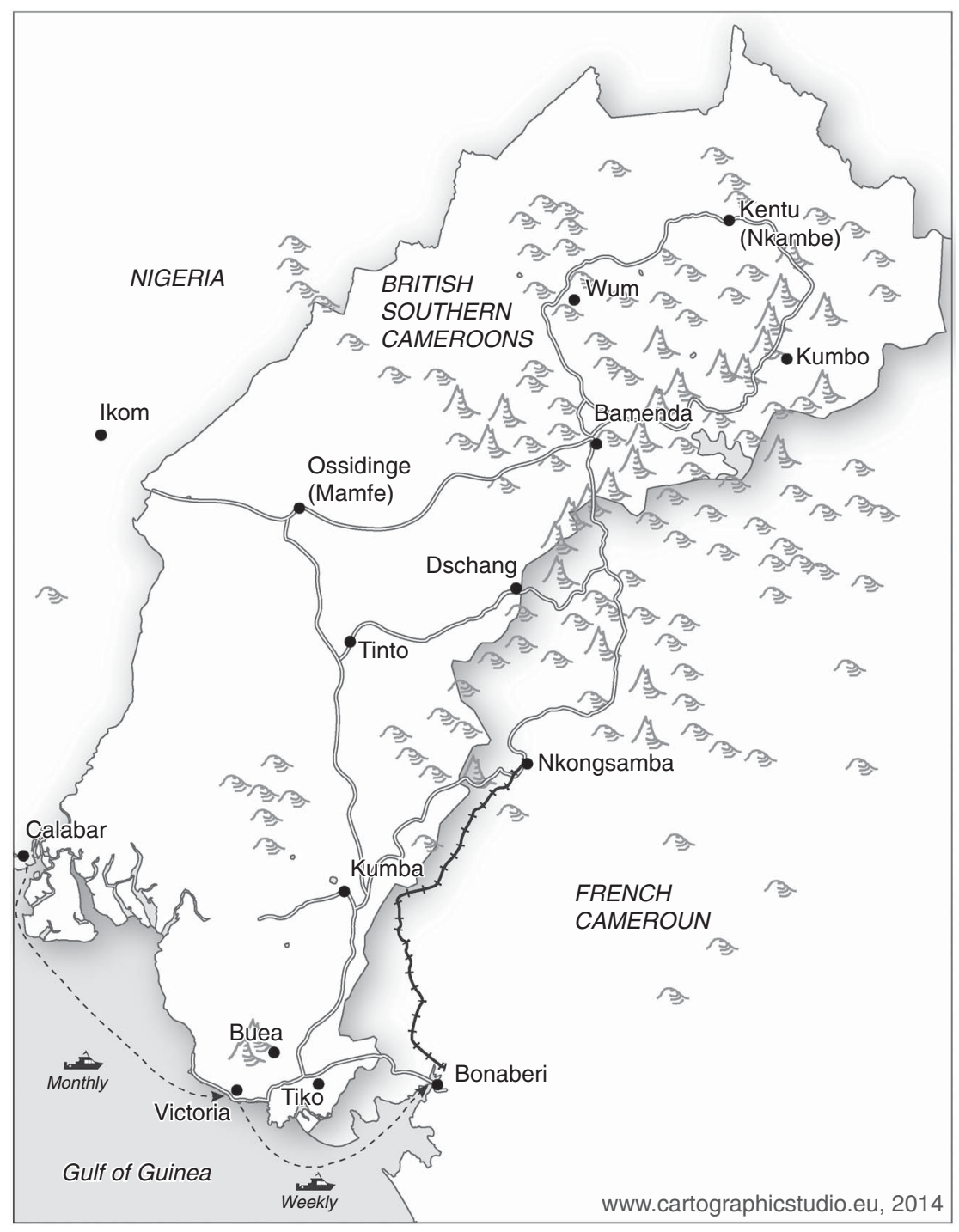

Figure 4. Transport water-rail-road.

Tiko, there is the ordinary Mail Steamer Service to Victoria about once in five weeks, from Tiko to Bonaberi there is the French weekly service between Bonaberi and Tiko which leaves every Wednesday, the train service to Nkongsamba leaves Bonaberi every Monday and Thursday. In my opinion this is the one and only satisfactory way for mail and packages to be dispatched. ${ }^{19}$

I9. NAB, File no. Ir/1917; Bb (1917) 3 Flag Post System. 


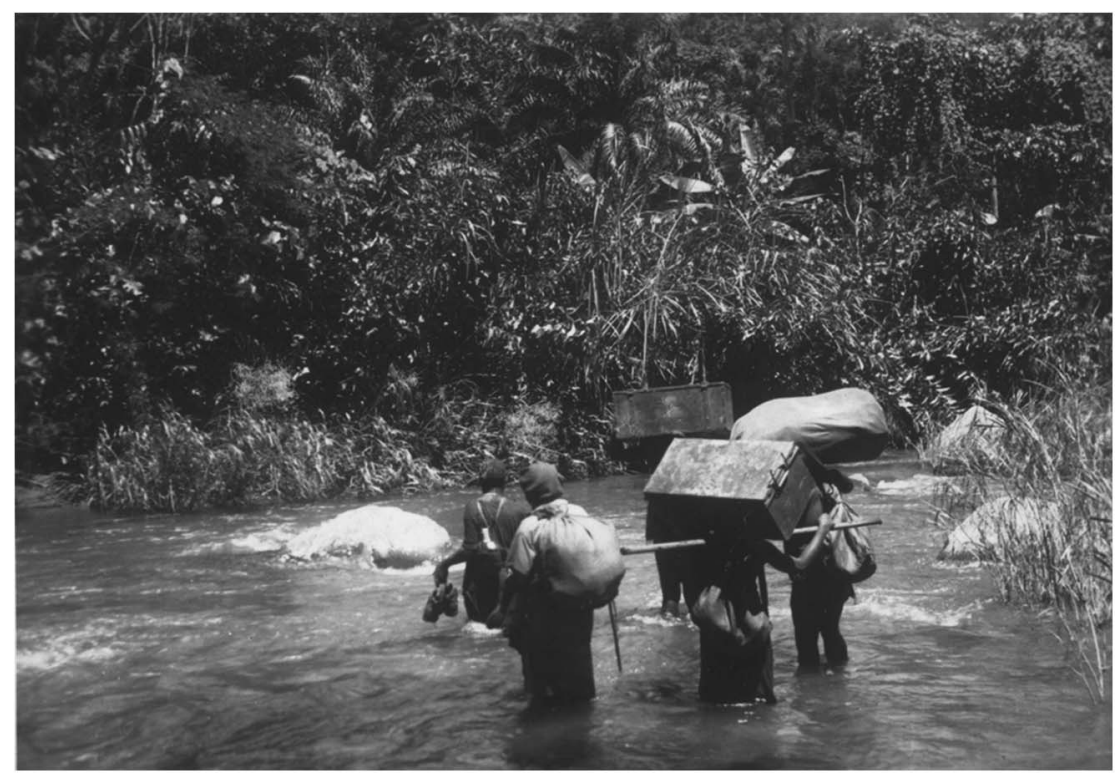

Figure 5. Mail runners bearing inland mail crossing a flooded river, I953.

Mission 2 I Archives Basel (Switzerland). Used with permission.

A mail relay runner arrived in Dschang from Nkongsamba every Saturday with mail for Dschang and Bamenda. In the initial stages there was no flag post between Bamenda and Dschang and so the mail had to be sent via Tinto. The port of Douala (located opposite Bonaberi, on the other side of the Wouri river) and the Nkongsamba railway terminus were vital links for mail destined for Dschang and Bamenda (see Figure 4).

\section{THE FLAG POST RUNNER}

As can be seen in Governor General Duff's memorandum quoted above, the task of the mail runner was difficult. Distances and loads were excessive: twenty-five to sixty miles on foot on a regular basis is challenging, even without having to carry a load, and the terrain was not easy to "run" due to the preponderance of rivers, hills, and forests. Southern Cameroon is mountainous, with peaks ranging from 3,000 to 4,500 metres above sea level. Regardless of whether the terrain covered forests, fast-flowing streams, and high peaks, the colonial administrator expected the mail to be forwarded without delay. The Resident in Bamenda, G.S. Podevin, aptly captured it thus: "At whatever hour of the day or night a letter or message or parcel is received, it is the duty of that post mail runner to forward it onto the next without any delay 
whatsoever." ${ }^{20}$ The British colonial administration depended on the mail runners, and the runners had to follow the instructions of the colonial administration regardless of the weather, or the time of day.

The physical condition of the mail runner was important. As a result, doctors were employed by the colonial service to certify that mail runners were fit enough to carry out their duties. As far as the physical nature of the mail runner was concerned, Captain L.W.G. Malcolm, writing in 1917, said: "In physical appearance, the men are well built and in many cases are of excellent physique. It is an extraordinary thing that whenever men have been recruited [...] they always turn out to be first-class shots. This has been remarked over and over." ${ }^{21}$ Such an encomium appeared to be something of an embellishment. This admiration for the physique of the runner co-existed uneasily, as we will see below, with equally regular complaints about his sluggishness.

\section{Recruitment and speed}

The mail runners were recruited by the chiefs, who were the representatives of the indigenous administration and mediators between the colonial administration and the indigenous population. Colonial statistical sources show that in 1917 Bamenda division alone employed a total of 135 "boys" at 45 flag posts. ${ }^{22}$ The high numbers in the Bamenda division might be explained by the fact that it was the largest of all the divisions and had a tradition of strong centralized kingdoms. The mail runners supplied by the chiefs were mostly the sons of palace guards and came from influential families in their chiefdoms. ${ }^{23}$ The chiefs signed the contracts on behalf of the mail runners.

Once recruited, the "first commandment" given to the mail runner was speed. Speed was essential because mail was a central form of communication for the colonial administration. In addition, this administrative mail - colonial reports, League of Nations and United Nations Trusteeship reports, ${ }^{24}$ and other types of dispatch - needed to be transported onwards by ship; ships or

20. NAB, Confidential Report, no. I/ı916, Bamenda, 28 February 19ı6, Flag Post by G.S. Podevin. 2 I. Captain L.W.G. Malcolm, "Notes on the Cameroon Province (with Special Reference to the Bamenda Division", The Scottish Geographical Magazine, 36 (1920), pp. 145-1 53.

22. NAB, File no. 60/16 Cb 1916, 9 Bamenda District: Administration 1916-1917.

23. NAB, File no. Ag/235, Flag Post System in British Administration: A Commentary.

24. The League of Nations (1919-1939)/United Nations (1945-) Trusteeship reports merit some attention here. In 1919, the year in which the League of Nations was created, Cameroon became a Mandate "B" territory. The League of Nations was charged with overseeing the political, social, and economic development of the territory. In 1945, the League of Nations ceased to exist and was replaced by the United Nations. Like the League of Nations it oversaw the economic, social, and political development of the territory. But it differed from the League of Nations in that it was to prepare the territory for self-government and independence. The League of Nations sent its reports to its headquarters in Geneva, while United Nations reports were sent to its headquarters in New York. 


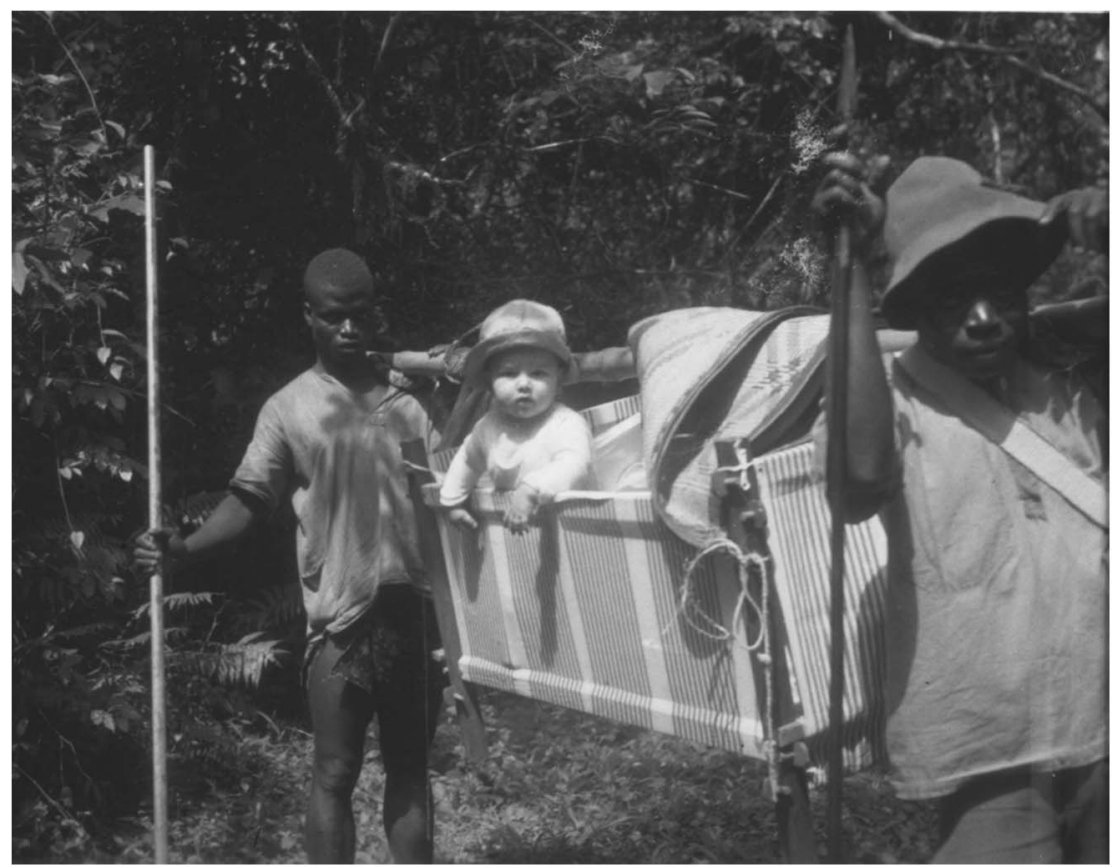

Figure 6. Mail carriers carrying loads for European administrators, and sometimes even carrying Europeans themselves, 1945 .

Mission 2 I Archives, Basel (Switzerland). Used with permission.

steamers could not wait once the tides were right, and any mail had to arrive on time. There were two main ports in British Southern Cameroon: Tiko and Victoria. Elders \& Fyffes ships left Tiko once a month carrying mail, firstclass passengers, and bananas from the plantations. Elder Dempsters, in turn, maintained a monthly service between Victoria and various Nigerian ports and their ships. Together with those of other well-known West African Lines such as Palm Line and Guinea Gulf Line, these provided a regular intercontinental service between Victoria and Great Britain and Europe. ${ }^{25}$ It was because of these ships' schedules that speed was central to the transportation of mail within the territory. At the same time, when compared to other parts of the empire, like India, ${ }^{26}$ the notion of "speed" in British Cameroon was not properly defined or standardized and was thus difficult to calculate.

Any mail runner carrying mail was, as his title suggests, supposed to move at speed, and there was to be no break or conversation with anybody along the way. The colonial administration sanctioned any mail runner who was caught in conversation while transmitting the royal mail. Colonial laws 
were severe when it came to punishing defaulters who delayed the mail, be it either through conversation with others or through rests. For instance, a mail runner was sentenced to five years' imprisonment and a fine of $£_{10}$ in Bamenda division in I93 I because he was caught conversing, instead of running with the mail. Another was sentenced to ten years in prison in I94 I because he was caught resting under a tree in Kumba division. Such cases of imprisonment became rampant. People who saw mail runners conversing or resting were encouraged to report them immediately to the nearest administrative station and were subsequently rewarded for their reporting of cases with a few shillings. ${ }^{27}$

There were also exceptions to the rule. Some mail runners had to alternate their duties by carrying the luggage of European administrators who had just arrived in the territory by ship and were going to work in the hinterland. In such situations, they were required to rest with their European superior, who was not used to travelling long distances on foot. Even those officials who were transferred within the colony needed mail carriers to help them transport their belongings and their children. ${ }^{28}$

\section{Wages and image of the mail runners}

Wages varied from division to division. Between I91 6 and 1922, in Kumba division, the three flag post "boys" received $£_{2}$ each $^{29}$ for covering the distance of the three flag posts. In Dschang division it was $\mathfrak{E}_{\mathrm{I}}$ for three posts; in Ossidinge division they received $\mathfrak{E}_{\mathrm{I}} \mathrm{O}$ a month for twenty-one posts. Bamenda division, covering the largest area and having the highest population density, had the largest number of flag posts and also employed the highest number of runners, who received $£_{\mathrm{I}} 5$ per month. ${ }^{3 \circ}$

It is clear that in the early years (1916-1922), the wages of the mail runners were not standardized, and each government official proposed an amount that he was willing to offer. But in later years, for example in 1937, the Resident for Cameroon Province, G.H. Findlay, suggested a rate of $£_{\text {IS }}$ per month, though he was ready to pay up to $£_{17} 6 \mathrm{~s}$ a month, ${ }^{3 \mathrm{I}}$ on condition that better and stronger men were made available to the service.

27. Interview with Benedicta Young Mukalla, Bamenda, 23 October 2010.

28. Mission 2i Archives, Basel, File no. BMCA-E-30.87.056, Transportation of Missionary goods, child in his baby cot to the hinterland station.

29. NAB, File no. Ba (I92I) 4, British Mandate for the British Cameroon.

30. See NAB, Memo no. 88/2/1 8 from Divisional Office, Ossidinge, to the Resident, Buea, 20 March 191 8; File no. 14/37/191 8 from the DO Dschang Cameroon Province to the Resident Buea, I6 February 1918; File no. 339/15/17 from District Officer's Office Kumba on Tour at Buea, 28 June I9I7, to the Resident, Buea titled "Flag Posts".

3I. The abbreviations used are: $£=$ pound, $s=$ shillings, and $d=$ pence; $£_{\mathrm{I}}=20$ shillings, and $\mathrm{I}$ shilling $=\mathrm{I} 2$ pence. 


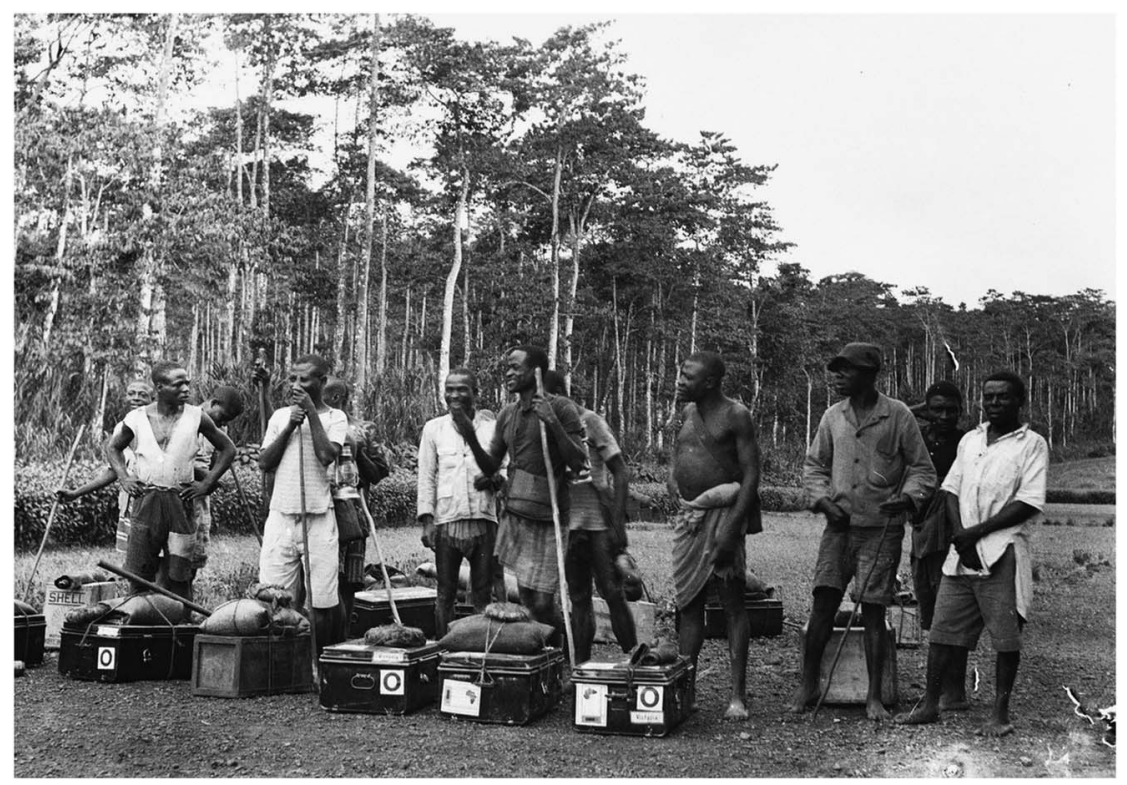

Figure 7. Resting with the mail and parcels destined for the hinterland, I946.

Mill Hill Archives, Oosterbeek (The Netherlands). Used with permission.

One wonders why he opted to pay more, but one might speculate that mail runners were in short supply because of a corresponding increase in the demand for labour on the coastal plantations, with promises of a secure wage and less risk. For instance, labour statistics for the plantations suggest that between 1937 and 1938 the number of workers of British Cameroon origin rose from 13,924 to 17,799 , a significant increase of $3,875 .{ }^{32}$ In some cases, as in Bamenda division in I9I 8 , the Resident, G.S. Podevin, was already giving an advance of 2 marks to ten men who were recruited and another eight were advanced 3 marks. ${ }^{33} \mathrm{He}$ also proposed that recruited mail runners be paid $£_{17} 6 \mathrm{~s}$ in English currency or the equivalent in marks. In 1918 , the Resident offered $7 \mathrm{~d}$ or $8 \mathrm{~d}$ a day for mail runners. ${ }^{34}$

32. Simon Joseph Epale, Plantations and Development in Western Cameroon, I885-1975: A Study in Agrarian Capitalism (New York, 1985), p. I 33.

33. NAB, File no. 4I6/17, Qe (I9I7) 4, Mail runners Permanent. Although this was a period of British control of the territory, the German mark (and not sterling) was used as a medium of exchange.

34. NAB, File Rc 1956/2 Cameroon Road Programme Policy. See also The National Archives, Kew, London [hereafter, TNA], PRO CO $583 / 248 /$ I I Cameroon Report on Road Communication; NAB, File no. Qc (I960), Kenneth E. Berill to J.O. Fields, The Economy of the Southern Cameroon: A Report Submitted to J.O. Fields, Commissioner of Southern Cameroon, 25 August 1960. 
Table 2. Official one-way journey rates for the runner, 1920.

\begin{tabular}{lcr}
\hline Division & Shillings & Pence \\
\hline Bamenda to Dschang & 1 & 9 \\
Bamenda to Tinto & 2 & 11 \\
Bamenda to Nkongsamba & 4 & 8 \\
Bamenda to Ossidinge (Mamfe) & 4 & 8 \\
Bamenda to Bagam & $1 / 2$ & 5 \\
Bamenda to Ikom & 8 & 2 \\
Ossidinge to Dschang & 4 & 6 \\
Ossidinge to Bamenda & 5 & 0 \\
Ossidinge to Buea & 7 & 6 \\
Ossidinge to Ikom & 3 & 0 \\
Victoria to Kumba & 8 & 0 \\
\hline
\end{tabular}

Source: NAB, File no. Qe (I920) 2, Approved Rates of Mail Runners Southern Provinces - Current from Ist January 1920. General Orders - XVIII - Paragraphs 34, 1920.

It is interesting to note that both pounds and marks were used at the same time during the early years of British colonial administration, but as the British established their authority over the territory the pound completely replaced the mark. Cameroon's first colonial administrator was German, and after World War I the territory was partitioned between France and Britain. Bamenda fell under British control, and during the nascent years of its administration both currencies were in circulation. The increase in pay, whether in pounds or marks, was meant to lure runners and discourage them from going down to the plantations. This seems to have met with very little success.

Wages were ultimately standardized. For instance, approved rates of payment for mail runners were established in 1920 for Cameroon Province (see Table 2 above, for one-way transport). Day rates were also established. For instance the daily rate for the Victoria division was $8 \mathrm{~d}$ when the runner was carrying a load and $4 \mathrm{~d}$ when he was not carrying a load. Elsewhere in the province, the daily rate for mail runners was $6 \mathrm{~d}$ and $3 \mathrm{~d}$ respectively. ${ }^{35}$ A "retention" rate $-\mathrm{a}$ rate paid when runners had to wait before continuing with the transportation of goods - of $3 \mathrm{~d}$ a day was paid in Victoria division and of $2 \mathrm{~d}$ elsewhere in the province. This rate was payable in lieu of a daily rate for days of employment when no running was involved or when there were compulsory halts on special journeys. Officers could engage mail runners at a lower rate than the ones above, depending on such aspects as the type of terrain and the type of 
load to be carried. The rate paid depended, above all, on the budget at the disposal of the colonial officer. This depended on the Native Authorities, which were the basic units of the British administrative system and used partly in generating revenue. ${ }^{36}$

Table 2 provides data on special journey rates for the one-way transportation of loads. In this case, the carrier had to make the arrangements required for any return journey on his own. These rates were calculated according to the distance covered by the runners. The lowest was from Bamenda to Bagam, a territory that was transferred from British to French Cameroon in the I920s. There were three possible reasons why the runners to Bagam received the lowest rates. In the first place, the distance to Bagam was $22.2 \mathrm{~km}$, while the distance to Dschang was $37 \mathrm{~km}$. Second, the terrain from Bamenda to Bagam was low lying, grassy, and void of any big rivers. Another reason could just have been the whims and caprices of the colonial administrator. Later, in 1947, the Secretary of the Eastern Provinces of Nigeria and the Cameroon laid down approved rates for the payment of mail runners. From then on, mail runners received $9 \mathrm{~d}$ a day when they were loaded, $4 \mathrm{~d}$ a day when they were not, and $2 \mathrm{~d}$ a day retention rate. The Bamenda DO at that time had proposed payment of i s per day for loaded mail runners, $6 \mathrm{~d}$ per day for unloaded mail runners, and $4 \mathrm{~d}$ a day as retention pay. ${ }^{37}$

There were serious implications for social change as a result of paying wages to mail runners. With wages came new forms of life in the economy. Having money meant that the mail runners could pay the colonial taxes that were used to grease the colonial machinery. They could also afford better medical treatment for their families, and, above all, pay school fees for their children. Acquiring new clothes, building new types of houses, and buying bicycles and gramophones, the mail runners adopted a lifestyle that gave them a new position in their society. The introduction of wages, and the possibility of acquiring "modern goods" led to a change in power relations and social hierarchies and gave way to the emergence of a new social group, a middling class considered advanced in comparison with other "traditional" social categories. ${ }^{38}$

The mail runner's job brought him close to the colonial administration, which, in the eyes of onlookers, translated into prestige. The mail runners were thus variously known in indigenous parlance as gheliikfaang, mikallade, wulbara, or wulmukalla, all meaning "modern people". The notions contained in these expressions - kfaang, mukalla, and mikallade - all denote newness, innovation, or novelty in thinking and action, as well as the material indicators and relationships that result from it. ${ }^{39}$

\section{Ibid.}

37. NAB, File no. C. 174/74, Qe (1947) I, Mail Runners Rates of Pay.

38. John Iliffe, The Emergence of African Capitalism (London, 1995).

39. Nkwi, Kfaang and its Technologies, p. I. 
Secondly, the challenges of the job and the robust constitution of the mail runners brought them respect among their kin. One of our interview respondents suggested that they were proud people. ${ }^{40}$ They felt socially superior because they carried the royal mail and also because they were among the first people to wear western clothes.

\section{MAIL RUNNERS AND THE COLONIAL ADMINISTRATION: RUPTURES AND CONTINUITIES}

\section{Mail runners' acts of resistance}

Given the challenges faced by the mail runners, one would expect some resistance to have emerged in response to these conditions and, more specifically, to European administrators. Mail runners were exposed to all types of danger: rugged terrain, high peaks, flooded rivers, thick forests, while running without rest in all weather at all times of day and night. These and various other individual and collective grievances did, in fact, lead to resistance to the colonial administration. Compared with other places and more advanced technologies, for instance in India where "class solidarities in the telegraph strike were formed directly through the communication system" ${ }^{4 \mathrm{I}}$ the heterogeneity and relative isolation of the mail runners in Cameroon tended to induce more individual forms of resistance. This could vary from sluggishness at work to abandoning mail and even stealing from the mailbags they were carrying. The contention was thus subtle in nature and belonged more to the sphere of "everyday forms of resistance". ${ }^{42}$

The Resident's in-tray was full of memoranda from the DO complaining about the activities of mail runners. A few cases might serve to illustrate the point. The DO of Victoria wrote to the Resident in Buea on 23 November I92 I as follows:

Dear Sir,

Several complaints regarding the mail runners' service between Buea and Victoria have been made and I have actually seen three mails and five parcels that have been lying at the flag post hut for ten days now [...]. This delay is excessive on the part of the mail runners and the necessary action needs to be taken to remedy the situation. ${ }^{43}$

40. Ngongtum Janarius, Interviewed by Walter Nkwi, Kom, Bamenda, 20 August 2009.

4I. Choudhury, "India's First Virtual Community and the Telegraph General Strike of I908", p. 47 .

42. James C. Scott, Weapons of the Weak: Everyday Forms of Peasant Resistance (New Haven, CT, 1985 ). For observations about resistance forms among another group of communications workers, telephone operators, in colonial British Cameroon in that period, see Walter Gam Nkwi, “Telephone Operators' Resistance to British Colonial Administration in the Cameroons Province, 1917-1931", Lagos Historical Review, I0 (2010), pp. 50-67.

43. NAB, Rg (1919) 6 Letter from DO Victoria to the Resident Buea, 23 November 192 I. 
To have abandoned mail was unforgivable in the eyes of the colonial administrator. This was contrary to one of the most important maxims of the system, which stated that at "whatever hour of the day or night a letter or message or parcel is received, it is the duty of that post mail runner to forward it onto the next without any delay whatever". ${ }^{44}$ Although many factors outside the influence of the runners might have delayed mail, longer delays, such as the one insinuated here by the DO, make it plausible to interpret them as mail runners actually contesting their working conditions.

The theft of a mailbag appeared to be one of the most serious forms of resistance among mail runners. Destroying the royal seal or making a hole in a royal mailbag upset the colonial administration, which responded accordingly. On s July 1930, the Acting Divisional Officer of Bamenda, L.L. Cantle, reported a case of mailbag robbery. While writing to the Health Officer, Banso, he wrote: "On your mail box being opened today and the cash inside checked it was found that the bag contained $£_{2}:$ I 4 only and not $£_{7}: I_{4}$ as stated in your cover letter.” This led to an inquiry into the mail runner who had transported the mailbag and what happened while the mailbag was being transported. On 10 July 1930, the medical officer wrote back to the DO: "I have made extensive enquiries and there is no doubt whatever that the amount $£_{7}$ : I 4 was placed into the bag [...]. Taking all the evidence, I consider either Ngo is the thief or he is in collusion with the thief. I have thus locked up his quarters and am confining him in the barracks." 45

The colonial administrators interpreted these incidents less as acts of resistance than as reflecting a lack of energy and responsibility on the side of the mail runners, as we can read in this extract from a letter from the DO of Bamenda, W.E. Hunt, to the Resident:

I admit that the mail service is very slow due to the sluggishness of the mail runners [...]. I am very strongly opposed to the present corps of mail runners who have proved themselves very unreliable and have also become insubordinate. Sooner or later again a theft will take place and/or a mail bag abandoned and it is practically impossible to fix responsibility when the mail bag passes through a score of different hands. ${ }^{46}$

Nevertheless, the colonial administration also reacted to these practices of mail runners in a way that indirectly reveals that they, in fact, read them

44. NAB, Confidential Report, no. i/ı116, Bamenda, 28 February 1916, Flag Post by G.S. Podevin.

45. NAB, File Rg (1930) 2, Letter from Assistant Divisional Officer, L.L. Cantle, to Medical Officer, Banso.

46. NAB, File Rg (193 I) Letter from DO of Bamenda, W.E. Hunt, to Resident, 30 December I930. 
as expressions of grievances, if not outright resistance. Thus, in a meeting of colonial administrators, six points were advanced by the DO to remedy the situation:

I) That there should be uniformed mail runners at villages about $\mathrm{I} 2$ miles distant from each other and paid Io/- a month. 2) They would have nothing to do but to pass the mail bags as received to the next post and return. 3) The mail runners would have to go day and night. 4) The mail runners will also be natives of the towns to which they are posted. 5) These new mail runners will have nothing to do but a weekly journeying or two to the next post. 6) The dismissal of all the present mail runners and the appointment of others who are obedient to the law and who will be bound by signed contracts signed by the mail runners themselves and not chiefs. ${ }^{47}$

The sewing of uniforms, the harmonization of wages, and the signing of contracts by mail runners themselves and no longer the chiefs were definitely improvements. They showed that subtle resistance on the part of the runners could yield dividends.

\section{Continuation of the mail runner system in "modern" communication}

Mail runners followed particular paths and tracks. Through constant use, these tracks became worn pathways along which roads would later be constructed. And some of those places in which flag post huts were originally located became prominent post houses in postcolonial Cameroon. Anecdotal archival evidence mentions the survey for the road network linking Victoria, Kumba, Mamfe, and Bamenda, with the Resident writing as follows: "The most important line of communication in the territory is the trunk road linking the port of Victoria in the South with Kumba-Tinto-Ossindige-Mamfe-Bamenda in the North. Rather than looking for new passages, I suggest we follow the mail runners' roads." ${ }^{8}$ The Resident's words were taken seriously and the road network was constructed along the route of the bridle paths used earlier by the mail runners. The telegraph construction across the territory relied heavily on the paths used by the mail runners, albeit with some deviations. The engineer in charge of surveying and wiring the territory, Lawson, sent a telegram to the foreman, W.W. Breaden, indirectly suggesting that there were going to be deviations from the original paths used by the mail runners. "Expect reach Ossidinge tomorrow. Stop. Road

47. NAB, Report by Her Majesty's Government in the United Kingdom of Great Britain and Northern Ireland in the General Assembly of the United Nations on the Administration of Cameroon Under United Kingdom Trusteeship for the year 1946.

48. NAB, File no. Rc 1956/2 Cameroon Road Programme Policy (NAB). See also TNA, PRO CO 583/248/ I I Cameroon Report on Road Communication; NAB, File Qc (1960) Kenneth E. Berill to J.O. Fields, The Economy of the Southern Cameroon: A Report Submitted to J.O. Fields, Commissioner of Southern Cameroon, 25 August 1960. 
from Nguti to Aschum is very difficult hilly country. Shall probably have to erect telegraph line along Nguti-Tinto-Ossidinge road but will advise you later. Stop." ${ }^{49}$

Although not very explicit about the deviation, the telegram indicates that the telegraph wires would not follow the exact routes used by the mail runners but that the mail runners' paths would serve only to indicate an initial direction. The wiring of the territory received additional attention in the mid-I930s, a period that can be seen as the heyday of colonial rule. The construction of such telegraph lines also called for labour. Writing to the DO of Dschang apparently asking for labour, the telegraph engineer, G.B. Hebden, said: "Instructions from His Excellency the Governor General are that the telegraph line between Buea-Kumba and Ossidinge is to be rushed with the greatest speed and I am in need of more labour. Can you send to me 1000 carriers?" 50 The request seems to have had the desired effect as the DO for Dschang sent $\mathrm{I}, 020$ carriers in response to help move telegraph poles, wires, and water. "I am sending this morning I020 carriers, the extra 20 to allow for any leakage." ${ }^{I}$ The telegraph lines were to be constructed from Kumba along the same paths used by the mail runners. However, "beyond Mabanda, the track passes through a very hilly country and [is] impracticable for the telegraph, thus there will be a slight deviation". ${ }^{2}$ It can thus be ascertained that the telegraph lines across the territory largely followed the old tracks created by the mail runners. Further, post offices sprouted up where the flag post huts had been. The post offices found today in Tiko, Victoria, Buea, Kumba, Ossidinge, Mamfe, and Bamenda are at the spots where flag post houses were initially situated. The mail runner system was thus the precursor of the modern communications system in British Southern Cameroon.

\section{The twilight of the mail runners}

With improvements in the territory's communications network, the system of mail relay runners gradually became redundant. With the initiatives in mind that had led to the birth of the mail runner system in the first place, it is clear that its success was due to the inadequate road and telegraph system in British Southern Cameroon. By 1955 the situation had drastically improved. A large part of British Southern Cameroon

49. NAB, File no. Rg (1933) I, Surveying of Telegraph Construction Communication in the British Occupied Territory of Southern Cameroon.

50. NAB, File no. Rg (1935) 3, Telegraph Construction, British Occupied Territory Cont'd.

s. Ibid.

52. Ibid. 
was linked by a motorable road network..$^{53}$ In addition, Austen lorries were already making their presence felt in the territory. ${ }^{54}$ This meant that the loads carried by the mail runners on their heads and backs could now be transported by motorized vehicles. British colonial administrators justified the construction of new and wider roads on the grounds that mail runners were generally more expensive than the motorcar. Frederick Lugard, ist Baron Lugard, often known as the father of indirect rule and who had worked in India, Uganda, and Nigeria as the British Governor, had stated as early as 1926 that human beings carried less, ate too much, and were liable to sickness and tiredness much more than had been expected.55 By 1955 , the mail runner was extinct, having been replaced by roads and modern post offices. ${ }^{56}$

\section{CONCLUSION}

For the colonial administration, the British-initiated mail runner system was vital in the transportation of mail by means of a relay system across the colony, and the flag posts became signposts on which today's modern road communications systems were constructed. They were the embodiment of the modern colonial state and the precursors of the contours of the modern present-day administration, as they underpinned the territorial communication that was one of the essential building blocks in the making of the state.

This article has demonstrated how, both as a communications technology and as a labour force, the runners were an indispensable part of the colonial administration. Although some resistance and/or insubordination to the system can be found, this was never organized beyond the level of individual resistance. Improvements in working conditions were made to maintain the system. Although the runners acquired a special social status in

53. See NAB, Report by Her Majesty's Government in the United Kingdom of Great Britain and Northern Ireland in the General Assembly of the United Nations on the Administration of Cameroon Under United Kingdom Trusteeship for the Year I95 I.

54. The history of the motor car in Sub-Saharan Africa has been studied for a long time. By 1940, French West Africa had about I0,000 vehicles. The expansion of the motor car in British West Africa was even more rapid. The number of vehicles imported into the Gold Coast and Nigeria in the I920s more than doubled and was twice the number arriving in the French colonies. See Anthony G. Hopkins, An Economic History of West Africa (London, 1973).

55. See Frederick D. Lugard, The Dual Mandate in British Tropical Africa (Abingdon, 1926), pp. $472-473$.

56. NAB, Files Ab 79, Report by His Majesty's Government in the United Kingdom of Great Britain and Northern Ireland to the Trusteeship Council of the United Nations on the Administration of Cameroon under United Kingdom Trusteeship for the Year 1949; Ab 8I, Report by His Majesty's Government in the United Kingdom of Great Britain and Northern Ireland to the Trusteeship Council of the United Nations on the Administration of Cameroon under United Kingdom Trusteeship for the Year 1950. 
the colonial state, they never developed to become a more coherent social group capable of collective action, as appears to have happened elsewhere in British colonial territories, as research from India shows.

An interesting conclusion can be drawn from Castells's notion in Communication Power of communication as the backbone of power relations of the modern state. ${ }^{57}$ The flag posts that were defined and situated by the British colonial administrators have always determined the communications system of anglophone Cameroon. Communication lines link geographical spots that have become hotspots and political/urban crossing points in the modern state. It is interesting to realize that these are based on power relations that date from colonial times and that today's road networks and other communications networks are linked to colonial governability. 